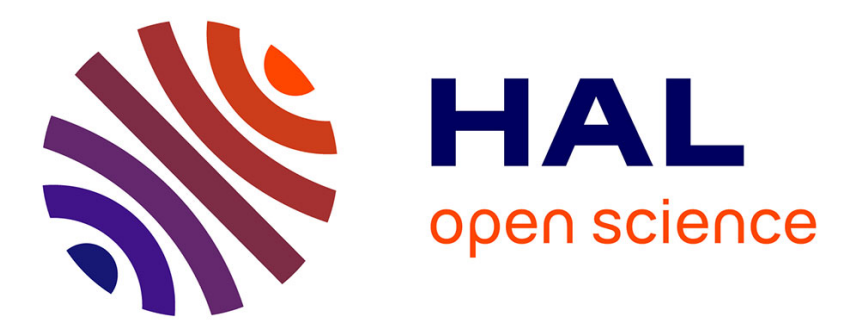

\title{
A 200 ka pollen record from Okinawa Trough: Paleoenvironment reconstruction of glacial-interglacial cycles
}

\author{
Zhuo Zheng, Kangyou Huang, Yun Deng, Linglong Cao, Saohua Yu, \\ Jean-Pierre Suc, Serge S. Berné, François Guichard
}

\section{To cite this version:}

Zhuo Zheng, Kangyou Huang, Yun Deng, Linglong Cao, Saohua Yu, et al.. A 200 ka pollen record from Okinawa Trough: Paleoenvironment reconstruction of glacial-interglacial cycles. Science China Earth Sciences, 2013, 56 (10), pp.1731-1747. 10.1007/s11430-013-4619-0 . hal-00929941

\section{HAL Id: hal-00929941 https://hal.science/hal-00929941}

Submitted on 17 Jan 2014

HAL is a multi-disciplinary open access archive for the deposit and dissemination of scientific research documents, whether they are published or not. The documents may come from teaching and research institutions in France or abroad, or from public or private research centers.
L'archive ouverte pluridisciplinaire HAL, est destinée au dépôt et à la diffusion de documents scientifiques de niveau recherche, publiés ou non, émanant des établissements d'enseignement et de recherche français ou étrangers, des laboratoires publics ou privés. 


\title{
A 200 ka Pollen record from Okinawa Trough: paleoenvironment reconstruction of glacial-interglacial cycles
}

\author{
ZHENG Zhuo ${ }^{1}$, DENG Yun ${ }^{2}$, HUANG Kangyou ${ }^{1}$, CAO Linglong ${ }^{3}$, YU Shaohua1, \\ SUC Jean-Pierre ${ }^{4}$, BERNE Serge ${ }^{5}$, GUICHARD François ${ }^{6}$,
}

1 Department of Earth Sciences, Sun Yat-sen University, Guangzhou 510275, China

2 CNRS UMR 5125, Paléoenvironnements et Paléobiosphère, Université Claude Bernard-Lyon1, 69622

Villeurbanne, France

3 South China Sea Marine Engineering and Environment Institute, SOA, Guangzhou, China 510300

4 Institut des Sciences de la Terre Paris, Université P. et M. Curie - Paris 6, 75005 Paris, France

5 Université de Perpignan Via Domitia, 66860 Perpignan, France

6 Laboratoire des Sciences du Climat et de l'Environnement, 91191 Gif-sur-Yvette, France

\begin{abstract}
Pollen analysis was carried out on the Core MD982194 retrieved from the Middle Okinawa Trough which was dated as old as 200 kyrs BP. The results revealed that pollen assemblages mainly presented an alternation of coniferous and herb pollen. The coniferous saccate pollen, principally Pinus and Tsuga, predominated in most parts of the core, especially highlighted in the interstadial stages including MIS 1,3, 5 and MIS7, whereas the herb pollen significantly increased in the glacial periods. Thus sharp change of their percentage was sensitive responding the transition between interglacial and glacial periods. Our record from this core has first documented that the percentage of Cyperaceae was extremely abundant in the glacial stages with the notably increasing in Artemisia, Gramineae, Asteraceae, Chenopodiaceae and freshwater algaes, which can be used as a proxy for sea-level change at the study site because of their close negative correlation of the orbital-scale changes in sea level. The distance between the continental coastline and the Okinawa Trough has deeply shortened due to the sea-level drop in the LGM. As a result, the sediment materials from Yangtze River was extensively deposited on the flat exposed continental shelf owing to the rapid decline of river flow speed, leading to that pollen grains from Okinawa Trough mainly derived from the flat coastal vegetation of exposed continental shelf at glacial stages, Changes of pollen assemblage were consistent with the variation of temperature and humidity, which showed that the percentage of arboreal pollen was highly augmented at MIS 7,5 and MIS 1, corresponding the strengthening of the East Asian summer monsoon and increasing of rainfall. Moreover, the peak of Pinus percentage in MIS 5.3, 5.1 and MIS 3.3 may be closely linked by orbital and sub-orbital cycles of solar radiation and monsoonal
\end{abstract}


variability. The present study of core MD981294 implied lower temperature and precipitation during the lowest sea-level stage (LGM), and more visibly testified that the vegetation of the flat plain on the exposed continental shelf was dominated by intrazonal communities such as halophyte grasslands and freshwater wetlands rather than zonal steppe or semi-arid desert. All above demonstrated that the fundamental changes of pollen assemblage and their origins in Okinawa Trough since $\sim 200 \mathrm{ka}$ BP were affected by combine factors including the coastline position and climate fluctuation. Moreover, the substantial shortening of distance between shoreline and the Okinawa Trough driven by orbital insolation cycles was clearly indicated by the pollen spectra, whereas, the source-area climate signal of the pollen record was largely weakened.

Keyworks: Okinawa Trough, Pollen analysis, East China continental shelf, Sea level, Terrigenous vegetation, Climate change

\section{Introduction}

The East China Sea is one of the broadest and most extensive continental shelves in the world, and the Okinawa Trough is a marginal sea as a new back-arc basin forming during the Neogene, which remained submerged during both the glacial and interglacial periods and, therefore, possesses a continuous record of Quaternary sediment. Being an ideal material for the research of marine environment and sea level changes since more than a decade, the intact sediment sequence of the Okinawa Trough provides abundant information on paleoenvironment and oceanography, in the light of relatively high sedimentary rate and stratigraphic resolution. In addition, as a key region linking eastern Asia mainland, continental shelves and Pacific Ocean, the Okinawa Through has been aroused widespread attention of researchers in the field of Quaternary sciences. The systematic studies on the paleoenvironment of the Okinawa Trough had began in the 1990s [1-5], relying on the cores drilled under the framework of Chinese-French cooperation on oceanographic survey in 1996 and International Marine Past Global Changes Study (IMAGES) program during leg 4 with R/V Marion Dufresne in 1998. These cores provided high-resolution materials for multidisciplinary studies such as stratigraphy, geochemistry, micropaleontology, palynology and so on [6-8].

The pollen analysis in Okinawa Trough is one of best method to explore the provenance of the deep sea sediment and reconstruct the terrigenous ecosystems [9-10]. The primal marine palynological studies in Okinawa Trough and its surrounding marine regions had begun in $1980 \mathrm{~s}$, but most of the works had poor age-control chronology and low resolution. In the recent years, many researches concerning the late Quaternary pollen analysis were carried on, and most of which were concentrated in north of the Okinawa Trough $[6,11,12]$. The previous works revealed that the pollen assemblages were predominated by herbaceous pollen in the glacial period, and the arboreal pollen, principally Pinus and fern spores, occurred and 
gradually replaced the herbs since the deglaciation. What is more, the pollen source areas were suggested mostly from the south of Japan. In the study of Kawahata, etc [6], a tropical pollen taxon Phyllocladus was found that was considered as a signal of in situ Kuroshio that had not shifted to the west Pacific Ocean during the last glacial period. The study on the cores of DGKS9602 and PC-1 towards the middle and north of the Okinawa Trough showed that the alteration of herb and Pinus percentage had good correspondence with the change of sea-level and oxygen isotope since the last glacial $[13,14]$. Recently, a high resolution record from DGKS9603 in the middle of the Okinawa Trough confirmed the expanding of wetlands and grasslands in the exposed continental shelf of eastern Asia during the Last Glacial Maximum (LGM), and afterwards the rapid increase in arboreal pollen in the Holocene [15].

The previous works provided abundant information on the variability of terrigenous fluxes and the reconstruction of marine and continental paleoenvironment. However, most studied cores had generally lengths within $10 \mathrm{~m}$ with the ages less than 50ka BP. The present study was based on the core MD982194 (approximately 30m) retrieved from the Middle Okinawa Trough which was as old as ca 200 ka BP., which so far documented one of the longest records in the area. Pollen analysis of this core provides useful data for reconstructing the history of vegetation, climate and oceanography during the last two glacial-interglacial cycles.

\section{Materials and methods}

MD982194 (280 $07^{\prime} \mathrm{N}, 127^{\circ} 22^{\prime}$, water depth $-989 \mathrm{~m}$, core length $\left.29.78 \mathrm{~m}\right)$ was one of the cores obtained during the fourth voyage in the framework of the IMAGES program in 1998, which was located in the western side of the Okinawa Trough (Fig.1). The distance of the studied core from the present margin of continental shelf at isobathymetric line of $-120 \mathrm{~m}$ is about $50 \mathrm{~km}$, and from that of $-200 \mathrm{~m}$ is only $30 \mathrm{~km}$. Lithological investigation showed that it is mainly composed of homogeneous, clayey silt including several sandy intervals. The color and bulk density of the sedimentation was analyzed at a resolution of $2 \mathrm{~cm}$ through the core. There were 136 samples spacing by $20 \mathrm{~cm}$ that had been analyzed palynologically [16]. The standard heavy liquid method and a combined HF technique were used for pollen preparation. The absolute pollen concentration was calculated using the volumetric method. An average of about 300 pollen grains were counted and identified for each samples, and at least 150 palynomorphs were counted excluding Pinus for all samples. The pollen percentages were calculated on the basis of the total pollen sum excluding aquatics, whereas the spores were based on the total sum that included both pollen and spores.

The chronology of the core was established using $\mathrm{AMS}^{14} \mathrm{C}$ dating and oxygen isotopes correlation. Two radiocarbon ages were $11347 \pm 41$ and $22145 \pm 81 \mathrm{yrs} \mathrm{BP}$ at respectively $110 \mathrm{~cm}$ and $330 \mathrm{~cm}$ of the core. The sample manipulation for carbon extraction was carried out in Guangzhou Institute of Geochemistry affiliating in Chinese Academy of Sciences, and afterwards measured in Peking University. The radiocarbon ages were calibrated by the method of Stuiver and Reimer (1998)[17-18], which are $12799 \pm 83$ and $26056 \pm 142$ yrs BP. A point-to-point correlation between our 
$\delta^{18} \mathrm{O}$ of Globigerinoides ruber with that of SPECMAP[19] and LR04[20] showed that $\delta^{18} \mathrm{O}$ curves were perfectly comparable among them at the orbital scale of glacial-interglacial stages, and the MIS 1-7 stages could be easily recognized (Fig. 2). There were then 6 tie-points used for the chronology interpolation, according to the oxygen isotope curves. The age model was then established by assuming constant sedimentation rates between two contiguous control points and extrapolation after the oldest control point. Judging from the oxygen isotope curve and the liner interpolation for the bottom, the study core, MD982194, represented a continuous sequence, and its maximum age was approximately $195 \mathrm{ka}$ at the bottom depth of $29.7 \mathrm{~m}$. The sedimentation rate was higher in the glacial period, especially in MIS 2 and MIS 6 stages reaching $16 \mathrm{~cm} / \mathrm{ka}$ and $22 \mathrm{~cm} / \mathrm{ka}$ respectively (Fig. 3). Oppositely, the rate was the lowest $(8.59 \mathrm{~cm} / \mathrm{ka}$ on average $)$ in the Holocene.

\section{Result of pollen analysis}

A plentiful of pollen taxa have been identified in the core samples, of which 51 arboreal pollen taxa (AP), 2 mangroves, 43 non-arboreal (NAP) and 3 aquatics, and several of fern spore and freshwater algae were recognized (Fig. 4). There were also some marine-borne microfossils such as dinoflagellates and diatoms.

The pollen spectra reflected the arboreal pollen taxa were abundant particularly in the interglacial periods, the most frequent of which belongs to Pinus with the percentage approximately $10-61 \%$ that averaged $30 \%$. The other common gymnosperms are mostly Abies ranging from $2.4 \%$ to $24.8 \%$ of the total pollen sum, as well as Taxodiaceae (3.2-14.2\%), Tsuga (2.0-12.6\%), Podocarpus (1.1-7.8\%), Cupressaceae (1.0-7.9\%) and Picea (0.7-5.2\%). While for the angiosperms, there are mainly Quercus (evergreen) ( 1.1-14.8\% ), Quercus (1.8-10.8\%), Fagus (0.9-6.8\%), Castanea-Castanopsis (0.5-4.7\%), Ulmus (0.9-3.2\%), Carpinus (0.9-3.4\%), Liquidamdar formosana( 0.3-3.6\% ), Juglans (0.3-2.3\%), Moraceae (0.3-2.0\%), Alnus (0.2-1.8\%) and so on. We discovered a few tropical mangroves, such as Rhizophora and Sonneratia.

Among the herbs, pollen of Cyperaceae was the most abundant in the core (the average and maximum percentages were respectively $18 \%$ and $40.3 \%$ ), the other frequent NAP chiefly belongs to Poaceae (3.9-12.6\%), Artemisia (3.4-11.0\%), Compositae (1.3-4.9\%), Chenopodiaceae (1.2-4.7\%), Typha (0.4-2.4\%), Polygonum (0.2-1.2\%) and Plantago (0.2-1.2\%).

The fern spores are mostly monolete spore of smooth exine which yielded $11.3 \%$ in average and $22.6 \%$ maximally of the total sum, and secondly trilete spores with 4.8 in average and $18.1 \%$ maximally. The other Peridophyta taxa include Pteris, Plagiogyria, Hymenophyllaceae, Hicriopteris, Lygodium and so on. A great number of algae have been found in some layers, the most frequent of them are Dinoflagellate (3.9-80.7\%), followed by Hystrichosphaera (1.9-9.5\%) and some fresh water algae like Pediastrum (0.5-3.2\%), Concentricystes etc.

The pollen zonation was facilitated by a stratigraphically constrained 
classification of pollen spectra using CONISS (Grimm, 1994). Seven pollen zones (1-7) were identified using the statistical method of constrained cluster analysis based on all taxa of the core (Fig. 4), and the zones 3, 5 and 6 were further divided into subzones. The seven pollen zones relating to the oxygen isotopic age model from MIS 1 to MIS7 are described below.

Zone 7 (2960-2840 cm, upper part of MIS 7): It is the oldest stage of the core containing 6 samples, equivalent to the corresponding age of MIS 7 and was characterized by a high percentage of Pinus as high as $43 \%$ and generally low percentage of herbaceous taxa with less than 14\%. Among the NAP, the Cyperaceae was $\sim 7 \%$, secondly Poaceae (4\%) and Artemisia $(2.7 \%)$. The broadleaved trees presented a rather low percentage. Whereas, the spores, specifically the triletes were highlighted, in contrast to the fresh-water algae that was scarce in this zone. The marine algae such as Dinoflagellate were abundant in the bottom of the zone.

Zone 6 (2840-1480 cm, MIS 6): The percentage of herbaceous pollen increased evidently, ranging from $37-57 \%$. The Cyperaceae was as high as $24 \%$, associated with Artemisia, Chenopodiaceae, Compositae and Poaceae that were also obviously increased. The aquatic pollen was especially more frequent. In opposite, the percentage of Pinus was notably decreased from previously $43 \%$ to $21 \%$. Other gymnosperms remained more or less stable, expecting for Abies that rose timidly. The deciduous broadleaved taxa, Quercus, Carpinus, Juglans, Fagus and Tilia increased. There was no variation in tropical pollen taxa. Otherwise, the monolete spores were sharply increased whereas trilete spores decreased. The fresh-water algae such as Pediastrum and Concentricystes were prominently enhanced, but the marine algae, Dinoflagellate was much lower than the previous zone. The zone 7 can be further divided into two subzones; the lower subzone $(2770-2000 \mathrm{~cm})$ was characterized by the least percentage of Pinus (13\%) which rose to $20 \%$ in the upper subzone $(2000-1480 \mathrm{~cm})$.

The zone 5 (1480-840cm, MIS 5): The pollen assemblages of this zone were substantially different in comparison with the zone 6 . The coniferous pollen contents in the zone 5 were largely increased, excepting for Podocarpus. Firstly, Pinus was $47 \%$ in average and reached $61 \%$ maximally. Secondly, the other saccate pollen like Picea, Abies and Tsuga were more abundant than the previous zone, in particular Tsuga showed a consistent augmentation in the whole zone. In more detail, the subzone $5 \mathrm{~b}(1200-920 \mathrm{~cm})$ was characterized by the evidence that the Gymnosperm pollen of Pinus, Abies, Picea, Cupressaceae and Taxodiaceae reached their highest value of the core. The broadleaved taxa, Quercus, Carpinus and Juglans presented a decreasing tendency, particularly in the zones $5 \mathrm{~b}$ and $5 \mathrm{a}$. As for the herbs, aquatics and freshwater algae, their relative contents evidently decreased. For example, the Cyperaceae was falling from previously $37 \%$ to $7 \%$. Among the Pterophyta spores, the trilete was abundant, with its highest percentage in the zone $5 \mathrm{c}$, while the monolete lowered. It is worth to mention that the marine algae, Dinoflagellate reached its highest level (12\% in average) in this zone, and even $20 \%$ in the subzone $5 \mathrm{~b}$. The most popular dinocystes was Spiniferites. 
Zone $4(840-700 \mathrm{~cm}$, MIS 4): The thickness of this interval is less than other zones. The pollen assemblages presented a sudden decrease in Pinus and Dinoflagellate. Meanwhile, the broadleaved taxa such as Quercus, Fagus, Castanea, Ulmus and many herbs as Artemisia and Cyperaceae increased relatively. Moreover, the monolete spores had its highest peak (averagely 13\%) of the core.

The zone 3 (700-300cm , MIS-3): The main feature of this zone was represented by a distinct increase in Pinus in the subzone $3 \mathrm{~b}$ and an afterward decrease into $3 \mathrm{a}$. A growth in Quercus was also observed, however the other broadleaved taxa maintained unchanged. As for NAP, the Cyperaceae showed a gradual rising tendency, particularly in the subzone $3 \mathrm{a}$, which was accompanied by the rise in freshwater algae like Pediastrum and so on. Whereas, the terrestrial herb pollen remained unchanged.

Zone 2 (300-120cm, MIS 2): There was a notably variation of pollen assemblages compared with the previous zone. The Pinus went down to $14 \%$ in average. The other taxa with large decrease in percentage were Cupressaceae and some broadleaved trees such as Carpinus and Fagus. On the contrary, the percentage of Podocarpus was slight increased. This zone was marked by high percentage of Cyperaceae (averagely 30\%). The most prominent feature was the remarkably increase in Artemisia and Chenopodiaceae, which achieved their highest values of the whole record. Accordingly, the Pediastrum and Concentricystes were common with some abrupt fluctuation; meanwhile Dinoflagellate was rather scarce.

Zone 1 (120-0cm , MIS 1): There was a sharp increase in the Gymnosperms such as Pinus, Tsuga, Cupressaceae, etc. The same rising was also observed for many broadleaved taxa like Alnus, Corylus, Carpinus, Fagus and Quercus. Oppositely, the herbs were significantly reduced, particularly Artemisia, Chenopodiaceae, Compositae, and Cyperaceae. The trilete spores went up modestly. The freshwater algae, Concentricystes and Pediastrum, were nearly lacking, by contrast the marine Dinoflagellate was conspicuously increased.

\section{Discussion}

Pollen record of the $30 \mathrm{~m}$ core clearly displayed the cycles of glacial-interglacial of the last 200 kyrs BP. The most distinct change is the alternation of Pinus and total herbs. The Gymnosperm saccate pollen, principally Pinus and Tsuga, increased during the interglacial periods of MIS 1, 3, 5 and 7 when the marine microfossils such as Dinoflagellate and marine diatom were relatively abundant. Whereas, the NAP, mostly Cyperaceae, Artemisia and Chenopodiaceae, predominated the pollen assemblages of the glacial periods, frequently associated with abundant terrestrial fresh-water aquatic pollen and algae (Pediastrum). However, pollen of broadleaved trees varied slightly. The identified pollen taxa are overall the popular elements of eastern China in the regions from subtropical to temperate zones. Therefore, the fossil pollen and spore for the greater part in the Okinawa Trough might derive from 
eastern Asia continent. However, the source areas were complicated because that the coastline substantially shifted during the transition from the interglacial to glacial stages that might affect the paleoenvironment interpretation of pollen spectra.

\subsection{Pollen taxa and their variation through the time sequence}

\subsubsection{Gymnosperms}

The Gymnosperm pollen with saccate, principally Pinus, Tsuga and Abies, have synchronous variations along with the glacial-interglacial cycles. Taking the Pinus for example, its percentage was merely $14-20 \%$ during the glacial periods, but it reached approximately $43-47 \%$ during the interglacial stages (Fig. 5). The same pattern was found for $T s u g a$, that its percentage, only $\sim 1 \%$ during the glacial periods, went up to over 4\% in MIS 1 and MIS 5 that is 4 times higher than the glacial intervals. Similarly, Abies was concordant with the change of ice cycles; and apparently more expressive in the subzone 5b. As for Picea, a relatively high value in MIS 5 was investigated, but it was low in the Holocene. It must be noticed that Podocarpus and Dacrydium, as coniferous saccate pollen with a geographical distribution in tropical and subtropical zones, changed differently in comparison with Pinus. The percentage of Podocarpus increased only in the last glacial stage (MIS 2).

What is the key point in affecting such percentage changes of Gymnosperm pollen? What is the direct or major factor, such as the climate changes at orbital-scale, or substantial shift of distance between coastline and the Okinawa Trough? It has been reported that Pinus is well adapted for long-distance transport by wind, and their relative values rise with increasing distance from the shoreline[13, 21]. Pinus, extremely abundant in the record of the Okinawa Trough, has been thought to have relatively high aerodynamic and hydrodynamic efficiencies and to be transported efficiently by both wind and water. An investigation showed that the dropping velocity of Pinus pollen grains in water were more rapid than other pollen, suggesting that hydrodynamic transport efficiency is lower than the herbaceous pollen [22]. Therefore, it can be concluded that the high percentages of Pinus and Tsuga in the interglacial stages resulted dominantly from the wind transportation. In other words, when sea-level was uprising during the interglacial periods, the distance between coastline and Okinawa Trough was largely extended, resulting in rapid reduce of terrestrial pollen flux from river runoff and the relatively increase of the eolian pollen supply by wind transportation. The Chinese isopollen map of surface Pinus showed the high percentage in the eastern China, and its distribution was consistent with $>600 \mathrm{~mm}$ rainfall isolines[23]. The blooming period of Pinus is generally in March and April when the winter monsoon was still prevailing. As a result, the pollen of Pinus during its flowering period could be greatly transported by dry wind blowing from continents to the ocean. This may explain the high percentage of Pinus, as well as Tsuga, in the interstadial sediment samples of Okinawa Trough. As relic specie from the Tertiary, the Tsuga is a tall plant and has large distribution areas in subtropical zone of China and Japan. In mainland China, Tsuga disjunctively distributes in the southwestern mountains (Hengduan Mountain and parts of eastern Himalayas), the central mountains (Qinling-Dabashan areas) and the southeastern 
mountains [24]. The species, Tsuga chinensis, is a dominant species in the subtropical mid-mountain coniferous forests and mixed forests, and $T$. longibracteata is widespread in the southern mountains. It is then suggested that the pollen provenance of Tsuga in the deep sea sediment of Okinawa Trough might be surrounding the areas of subtropical mountains in eastern China (regions to the southward of Qinling mountain ranges), Taiwan Island, and southern Japan. However, the low percentage of Podocarpus and Dacrydium in the interglacial stages was possibly caused by their geographical distribution and blooming seasons. Firstly, the flowering periods of the above tropical taxa are mainly in May when atmospheric humidity is relatively heavy, resulting in low pollen content in the air, and secondly, the summer monsoon is strengthened in May with the humid wind blowing from ocean to land. Moreover, the tropical regions are much farther away from the Okinawa Trough that limited consequently the number of tropical pollen being transported through long-distance in the air.

\subsubsection{Broadleaved taxa}

The most frequent broadleaved taxa were Quercus, Carpinus, Juglans, Fagus, Ulmus, Castanea etc. Their total percentage varied from $5 \%$ to $25 \%$ approximately. Their minimum value was found in the middle of MIS5 stage (pollen zone 5b). In fact, the majority of the broadleaved taxa varied slightly. The north subtropical-temperate types such as Carpinus, Juglans, Fagus and Ulmus were relatively higher in percentage during the glacial stages, for example in the lower part of MIS 6 (pollen zone 6a). Quercus (evergreen and deciduous), a dominant tree in the forest and the most important genus in the Fagaceae, began to increase gradually since MIS 4 and reached its maximum in the Holocene. Overall, the broadleaved taxa discovered in the Okinawa Trough had geographical distribution of the north subtropical and temperate, among which little were evergreen elements. According to the modern vegetation and surface pollen data, the pollen source was more likely from the vegetation of mid-mountains of Changjiang River areas and the northward mountains. Virtually, the evergreen and deciduous broadleaved mixed forests have rather widespread distribution in eastern China and the south of Japan. Therefore, the percentages of broadleaved pollen either in the glacial or in the interglacial were low with small amplitude of variation. The synthetic pollen diagram showed that the group of subtropical evergreen broadleaved fluctuated around the relative value $10 \%$, whereas, the group of temperate deciduous varied surrounding $25 \%$. The two events of temperate trees with higher than $25 \%$ occurred in the interglacial period MIS 1 and MIS 5 stages (pollen zone 5b). The subtropical curve varied with the oxygen isotope when Pinus was put inside the group, however, the source of Pinus could not be confined, and as mentioned above, the variation of Pinus pollen was caused more

likely by the modifications of transport media and transport distance rather than climate changes of the source areas.

\subsubsection{Herbs}

The relative amounts of NAP taxa increased significantly when the arboreal 
pollen, principally Pinus, largely reduced. The result revealed that the pollen content of herbs varied sensitively according to the marine oxygen isotope time sequence driven by glacial-interglacial cycles. Consequently, the herbaceous taxa can be regarded as one of the best proxy of evaluating the paleoenvironment of the source areas. According to the percentage, the NAP changed at a range from $10 \%$ to $40 \%$, in which Cyperaceae varied most significantly with $25-30 \%$ in the glacial interval that was $\sim 5 \%$ in the interstadial. The other associated pollen taxa with higher contents during the glacial stages were Artemisia, Poaceae, Compositae, Chenopodiaceae etc. Artemisia achieved its highest level at the LGM, in general it was 1-2\% in the interstadial, $\sim 5 \%$ in the glacials and $\sim 10 \%$ in the LGM (Fig. 6). It is worth to remark that in the glacial stages, the aquatic pollen and freshwater algae went up simultaneously along with the herbs. The most characteristics were, for example, Pediastrum, Concentricystes, Polygonum, Potamogeton, etc. The booming of herbs and aquatic taxa confirmed the existence of widespread grasslands and wetlands on the exposed continent shelf during glacial stages (in particular MIS2-4 and MIS6).

Sedge is a perennial or annual herb, mainly growing in the humid lowlands, peats or surrounding water areas, and some species occurred in the alpine meadows. The surface pollen data in the East China Sea showed that the percentage of Cyperaceae was in general $1.5 \%$ [25]. The transport distance of sedge pollen was usually short; therefore, the vast emerging of Cyperaceae indicated the dropping of sea-level causing the massive alluvial plains and wetlands. And the only reasonably explanation of the origin of Cyperaceae was the exposed continental shelf after falling of sea-level. The fresh water algae were also demonstrated such claim. According to the previous study, it was characterized by the growth of Artemisia, Poaceae, Chenopodiaceae and Cyperaceae[15]. As the location of this core is really close to the coastline in the glacial stages, there would be much variation in the source of terrigenous material in different locations. And the significant increase in herbs in the Okinawa Trough was virtually corresponding to the vegetation in the exposed continental shelf in the glacial periods.

\subsection{Climate and sea level changes indicated by pollen assemblages}

\subsubsection{Sea level change}

The bathymetric line of $130 \mathrm{~m}$ in the East China Sea continental shelf is located near the Okinawa Trough where has a distance of about $400 \mathrm{~km}$ from the present-day coastline of Yangtze River mouth. The rapid lowering of sea level at the glacial periods resulted in substantial movement of the coastline that had a great influence on terrigenous materials and source areas of the sediments. Therefore, it is important that taking into consideration of source area and transportation pattern of sedimentary materials respectively at glacial and interglacial episodes for interpretation of continental vegetation and climate. In other word, in surrounding continent and islands, where should be the major provenance areas that the pollen spectra and related vegetation reflected and, if the pollen provenance areas had shifted substantially during glacial and glacial episodes?

To correctly clarify the above issues, the distance estimation of coastline shift 
during glacial-interglacial is a prerequisite for understanding the variability of transportation models. A nearby core DGKS9603 has shown that on the glacial-interglacial scale, terrestrial supply to the Okinawa Trough was mainly controlled by sea level changes via changing the relative distance between the Yangtze River mouth and the Okinawa Trough, and during the Last Glacial maximum and cooling events (Heinrich events), the East Asian winter monsoon would have intensified and thus provided much eolain dust to the Okinawa Trough [26]. The main chemical compositions of the core $\mathrm{E} 017$ sediments are $\mathrm{SiO}_{2}, \mathrm{Al}_{2} \mathrm{O}_{3}, \mathrm{CaO}$ and Total $\mathrm{Fe}_{2} \mathrm{O}_{3}$, and then $\mathrm{K}_{2} \mathrm{O}, \mathrm{Na}_{2} \mathrm{O}, \mathrm{MgO}$ and $\mathrm{MnO}$, which are similar to those of the shelf sediments in the East China Sea. In comparison with the Holocene, the sedimentation rate at the last deglaciation is higher, the grain size is coarser and the elements of terrigenous debris such as $\mathrm{SiO}_{2}, \mathrm{Al}_{2} \mathrm{O}_{3}, \mathrm{~K}_{2} \mathrm{O}$ are higher, and the biogenic elements such as $\mathrm{CaO}$ and $\mathrm{Sr}$ are relatively low[27]. It can be concluded that the distance between coastline and Okinawa Trough shortened at the glacial periods, resulting in the large increase of terrestrial supply mainly derived from the continental shelf. Consequently, the provenance of pollen supply mostly derived from the vegetation covers on the continental shelf that spread over hundreds of kilometers. In addition, the East China shelf was a huge low-lying alluvial plain of Changjiang and Huanghe Rivers, and the frequent flooding disasters caused that the tree seedlings could not survived, but rapid development of wetland and grass (Fig 7).

By contrast, during the high sea level of the interglacials, it was difficult for the terrestrial material transporting through long distance in ocean of the East China Sea from the river mouth into the Okinawa Trough. As a matter of fact, the complex ocean currents in the East China Sea driven by Pacific circulation and seasonal sea surface temperature obstructed terrestrial pollen grains from being carried and traveling long distance in water to the Trough areas. The pattern of late Holocene sedimentation showed that $80 \%$ terrigenous mud from the Changjiang deposited in the inner shelf, a great of which stopped in the river mouth and the sub-marine delta, and an other Holocene sediment center was the offshore near Zhejiang and Fujian carried by southward coastal currents [28]. According to the clay fraction using ICP-AES from the core DGKS9603 testified that the last glacial (41.0-11.2 ka BP) was characterized by high amount of terrigenous source materials, whereas the Holocene mainly by marine biogenic components [29]. It is then suggested that the majority of river supply materials including pollen grain deposited in the inner shelf, and few could travel through the whole East China Sea to the Okinawa Trough. These facts add up to an insignificant amount of pollen supply in water during the high-stand sea level stages, implying that the proportion of air-born pollen, in deep sea sediment, plays an important role of the continental source and the eolian transportation may be more important than the river input. The Pine pollen was well known as a long distance wind-blown particle that was found abundant in samples of interglacial stages. The pine pollen was mostly carried by the northwest wind of winter monsoon during the flowering season in March and early April. In the present study of MD982194, the high percentages of Pinus were respectively occurred in the time-intervals of MIS 1 、 
MIS 3.3、 MIS 5 and MIS7, implying close relation with the high stand of sea level.

The substantial shift of the coastline at glacial and interglacial determined the pollen proportion of riverine or eolian origins. However, the eolian source was negligible in the sediment deposited during the lowest see level because that the paleo-river mouth was close to the Okinawa Trough leading to a great amount of direct terrestrial supply. The similar pollen transport and deposition pattern was also observed in north of the South China Sea [21].

Moreover, the result form MD982194 showed that the stages of low see level were marked by not only the high relative content of herbs, but also fresh water algae, indicating widespread distribution of grassland and wetland on the exposed continental shelf. The most remarkable feature is the predominance of Cyperaceae associated with abundant aquatics (Typha etc.) and fresh water algae (Pediastrum), which was concordant with the increase in terrestrial plant debris and charcoals (Fig 8). In addition, using scanning electron microscope (SEM), we have found pollen of Glyptostrobus of Taxodiaceae, a tree widely located in fresh water wetland in the southeast of China. The above evidence suggested that the exposed continental shelf was a big alluvial plain, on which there were anastomosing rivers, lakes and swamps covered with huge wetland vegetation ecosystem. The geophysical study testified that the paleo-valley of anastomosing river has only a degree of slope less than $1 / 10,000$ leading to the formation of unstable wandering river system. Some works displayed that there were at least 6 major river ways of Changjiang on the near paleo-river mouth at LGM [30]. However, it must be pointed out that some other pollen analysis from nearby cores, DGKS9602 and DGKS9603 for example, showed the predominance of Artemisia at glacial stage, suggesting uneven distribution of grass, swamp and fragmentary bosket. And the short-distance terrestrial provenance resulted in un-uniform sediment origins in different locality of cores.

In comparison of the sea level change, the pollen percentage of NAP related negatively with the global sea level (Fig 9)[31, 32]. Similar correlation was also found in the palynological study in the north of the South China Sea, in which the ratio between pine and herb pollen was used as a proxy of sea level change and shore line distance from the core site $[21,33]$. Therefore, the ratio of Pinus/NAP or total NAP can both be considered as a proxy of sea level or shoreline distance in the deep sea areas with large continental shelf such as the East China Sea and the northern South China Sea.

It must be indicated that the ratio of conifer sacate pollen and herb can only be used as a proxy of sea level change in the regions possessing huge continental shelf to which the big rivers flowed from continent mountains, and forming anastomosing river system on the shelf at the low sea level stages. The frequent disaster of flooding on the plain of exposed continental shelf leading to the difficulty of germination and seedling for arboreal plants. The good examples are the East China Sea and Yellow Sea where Changjiang and Huanghe are the biggest rivers in China. The northern South China Sea is also affected by Zhujiang River. However, the grassland may not be widespread in the coastal regions with narrow or without continental shelf such as 
in eastern Japan, eastern Philippine and so on. As well as the flat shelf without big river input [34]. It means that some deep sea cores could have pollen assemblages of low content of NAP for the glacial interval [35-37]. In summary, the proxy of pollen ratio or the herb percentage can only be used conditionally for marine sediment.

\subsubsection{Significance of climate changes and monsoon variability}

In order to evaluate the climate changes on the basis of pollen data, several ecological groups including subtropical and temperate types were divided (Fig 10). The herbs were classified into groups of dry-land and wetland. The evergreen subtropical arboreal pollen taxa were less than $15 \%$ in total along the core, and had no concern with warmer climate. It was found that the relative values of subtropical elements were slightly higher at glacial periods, in particular at the LGM. Similarly, the temperate elements had no relationship with cold episodes. In fact, the cold glacial stages were characterized by high percentage of NAP and particularly the dry-land grass which was higher than 5\% respectively in MIS 2, 4 and 6 . The herbs as Artemisia was especially abundant at MIS 2 possibly resulted from weakening of summer monsoon. By contrast, Pollen of Pinus can be used indirectly as a warm climate indicator, with its peaks over $25 \%$ at MIS 1, MIS3.3, MIS 5, and MIS 7.

Pollen assemblages from the Okinawa Trough were affected by both sea level and climate change, but the sea level influence controlled mostly the variation of pollen spectra. This pattern was displayed by low percentage of cold temperate elements such as Picea, Larix and Betula during the glacial periods, especially the LGM, but relatively high content of herbs that covered most areas of exposed continental shelf. The materials from upstream source of Chinese mountains were extremely rare for the samples of glacial stages in spite of high sedimentary rate [26]. This is because that the rapid deposition occurred when rivers flowed into the huge flat plain and slowed down immediately. Therefore, few mountain elements could be found in the Okinawa Trough, which must transport long distance of hundreds of kilometer across the flat plain. Besides, the colder climate and weakening of the summer monsoon resulted in lower rainfalls on the continent of source areas, causing obvious reduction of transport capability by river current. To summing up, the copious source of terrestrial materials of the glacial sediments from MD982194 derived mostly from the flat plains such as the exposed Donghai and Huanghai continental shelves, rather than upstream mountains of Changjiang. And the widespread distribution of grass and wetland on the exposed continental shelf made possible abundant supply of non-arboreal pollen during the lower sea level stand. The above sedimentation pattern reflected the combine influence of sea level, transport distance and climate (precipitation) on terrestrial source flux and pollen assemblage (Fig 9 and $10)$.

Oxygen isotope records of stalagmites from central and southern China provided important information in climate changes. Many absolute-dated records from cave supported the idea that tropical/subtropical monsoons respond dominantly and directly to changes in Northern Hemisphere summer insolation on orbital timescales [38-40]. In other word, the intensity of Asian summer monsoon plays a key role in 
shaping oxygen isotope variations of stalagmites in China on the timing scale of glacial/interglacial or stadial/interstadial. The observed changes were also related with the shift amplitude of the ITCZ, producing substantial variation of precipitations [41]. Our pollen result testified that the overall pollen assemblages of MD982194 respond dominantly to changes of sea level and ice volume on the scale of glacial/interglacial cycles (Fig 10). The change from glacial to interglacial was characterized by the transformation from NAP to Pinus pollen. All interglacials, MIS 7, MIS 5 and MIS 1, without exception, were marked by sharp decrease in NAP. However, some secondary details of pollen ecological group, particularly for arboreal pollen taxa, correlate with summer insolation and isotope curves of stalagmite in China. For instance, a reduce of subtropical elements and broadleaved trees in MIS 6.2 coincided with a deep variation of the oxygen isotope from stalagmite [40], and several peaks of Pinus took place in MIS 5.3, MIS 5.1 and MIS 3.3 (pollen zone 3b), implying certain response on precession cycles driven by solar insolation and summer monsoon. In fact, pollen assemblage varied with both ice volume and orbital or sub-orbital cycles were discovered in Pacific and Atlantic Oceans [42, 43]. The pollen result from the northern South China Sea had also found the obvious orbital cycles and half precession cycles [21]. The eastern Asia climate system has both "ice-sheet response" and "monsoon response" to orbital changes.

As is well known, the pollen assemblage in the deep marginal sea of the LGM mirrored the vegetation on the adjacent continental shelf. However, some previous pollen analysis disputed the environmental significance, and the most primary controversy focused on the question: the widespread grassland on the exposed continental shelf during the LGM indicated or not the zonal temperate steppe that extended from northwest of China to regions of Changjiang River and even the eastern China continental shelf? Actually, the high percentage of herb pollen was discovered not only in the Okinawa Trough, but also in the northern slope of the South China Sea where the predominant herbs were Artemisia and Gramineae, associated frequently with wetland elements [45]. The present pollen study from Okinawa Trough also revealed a high value of Artemisia and Cyperaceae. Hence is it possible that the vegetation at LGM belongs to zonal temperate semi-arid steppe under an annual precipitation lower than $450 \mathrm{~mm}$ ? If the above estimation was correct, it would suggest that the whole Chinese continent excluding tropical regions was as dry as desert condition. As a matter of act, the pollen taxa at LGM from MD982194 were composed of not only the terrestrial herbs, but also abundant wetland grass such as Cyperaceae and fresh-water swamp algae such as Pediastrum. Similar finding was as well in the South China Sea [33]. Besides, pollen taxa of typical desert such as Ephedra and Tamarix were few or lacking. Therefore, we can presume that the extensive plain of continental shelf was not covered by temperate zonal steppe, but with a complex ecosystem dominated by intrazonal grassland, wetland and some scatter bush or forest. The above ecosystem might be resulted from the weakening of summer monsoon, and also the continuing river input into the flat plain causing frequent flooding and forming wandering rivers with a great amount of swamps. 
As already indicated, although that the predominance of grass pollen during the glacial stages implied a intrazonal vegetation with precipitation higher than present-day zonal steppe condition, it was still considered dryer climate in eastern China resulted from the retreat of coastline and weakening of summer monsoon. This is in accordance with the simulation in East Asian climate at the LGM using a regional climate model (RegCM2) [46]. The simulation showed that the precipitation is complex, with general features of drier conditions over eastern China and its neighborhood than the present (Fig 11). In considering that the nowadays annual precipitation in the coastal areas of eastern China is around $800-1400 \mathrm{~mm}$, with an average $1200 \mathrm{~mm}$, even if a reduction level of rainfall was over $50 \%$ at LGM, the climate would be still wetter than zonal steppe in China. The temperature estimation on the basis of pollen data is relatively difficult, because little arboreal pollen taxa and small quantity of their pollen during the LGM had been found. Nevertheless, the pollen ratio of Artemisia/Poaceae (A/P), proposed by Zheng et al., (2007) [22], has climate significance with an increasing gradient from tropical to temperate zones. Pollen of Artemisia is higher than Poaceae to the north of latitude $\sim 30^{\circ} \mathrm{N}$, and lower to the south. Based on the average A/P ratio from core MD982194 for the samples of LGM, the latitude estimation was about $34.3^{\circ} \mathrm{N}$, implying that the vegetation zones shifted at least latitude $\sim 6^{\circ} \mathrm{N}$ southwards. Another core DGKS9602 in the vicinity estimated a lowering of mean annual temperature as much as $\sim 8^{\circ} \mathrm{C}$. The simulation (RegCM2) shows the coldest anomaly was about $8{ }^{\circ} \mathrm{C}$ in the vicinity of current coastal areas in eastern Asia, where land is exposed due to lowering sea level at the LGM. Therefore, the present estimation by means of pollen ratio is basically accordance with that of climate model.

\section{Conclusion}

A total of 51 terrestrial arboreal taxa, 2 mangroves, 43 herbs, 3 aquatics and some fern spores and algae were counted from the pollen analysis of core MD982194 in the Okinawa Trough. Many marine microfossils such as dinoflagellate and diatom were found. Result showed that the pollen assemblages changed fundamentally from the glacial to interglacial periods. The most remarkable feature is the alternation of Gymnosperm and herbaceous pollen. The saccate pollen grains Pinus and Tsuga were more abundant at MIS 1, 3, 5 and 7 with amplitude from $\sim 15 \%$ to $\sim 50 \%$, frequently associated with high amount of Dinoflagellate. By contrast, the NAP increased during the glacial periods, the curve of which sensitively correlated with oxygen isotopic stages. The range of NAP variation was between $\sim 10 \%$ and $\sim 40 \%$. The dominated herbaceous pollen was Cyperaceae that was accompanied with frequent occurrence of Artemisia, Poaceae, Asteraceae and Chenopodiaceae. The other associated palynomorphs were aquatic pollen and fresh water algae. The pollen of broadleaf trees, however, varied irregularly without any corresponding relation with glacial-interglacial cycles.

The identified pollen taxa mostly belong to the flora of eastern Asia distributed from the subtropical to temperate zones. It is then suggested that the general 
provenance of pollen supply in the Okinawa Trough is around the coastal areas of eastern China. However, in consideration of substantial shift of the coastline from glacial to interglacial stages, the pollen source and their transport medium might vary fundamentally.

During the last two glacial periods, the distance of the Okinawa Trough from coastline shortened distinctively leading to the rapid increase of terrigenous flux in the sediment of the trough. The dominant components of the terrestrial supply in the sediment derived from the flat plain of exposed continental shelf, particularly the front zone of the delta. The pollen from upstream mountains in the continent could hardly be transported into the Okinawa Trough by rivers, because that the quick slowing of water current in the huge flat alluvial plain will reduce the capacity of rivers for carrying terrestrial materials through a long distance resulting in deposition before reaching the oceans. The present study showed that the exposed continental shelf extended hundreds of kilometers where the swamps and wetlands had a considerable quantity. It can be suggested then that there were many anastomosing rivers and regionally covered with a huge grass-wetland intrazonal vegetation ecosystem.

The variation of NAP or PIN/NAP ratio has a close relation with sea level changes on the orbital time-scale, suggesting the pollen can be used as a proxy of sea level. However, the good relationship between high NAP and low sea level is only efficient in the areas with extensive continental shelf where underwent flooding of big continental rivers. Therefore, in the areas without large continental shelf, such as the east coastal sea in Japan and Philippines and so on, the NAP percentage may not predominate the glacial pollen assemblages. It means that the present pollen proxy for evaluating the sea level change can not be used everywhere in the world.

The fact of extensive development of grassland on the exposed shelf during the glacial stages suggested, to a certain degree, dryer condition. Regional simulation result based on RegCM2 for the LGM agreed with our pollen data that the annual precipitation was much lower than that of present-day in the coastal areas of eastern Asia; whereas, in considering the existence of subtropical trees and widespread wetlands, and lacking of typical desert pollen taxa, the glacial pollen assemblages was not comparable with modern zonal steppe, without mentioning that the semi-arid steppe extended from the northwest China to the east coastline and Changjiang downstream areas.

In general, the most remarkable changes of pollen assemblage coincided with the variability of ice volume and global sea-level on an orbital timescale. Some arboreal taxa, in addition, indicated the influence of insolation cycles, such as a sudden fall of subtropical evergreen broadleaved trees at MIS 6.2 which was also marked by the stalagmite oxygen isotopic evidence. Some peaks of Pinus such as in MIS 5.3、MIS 5.1 and MIS 3.3 corresponded as well the solar insolation and monsoon variability. The above evidences demonstrate that the substantial shift of the coastline leading to fundamental changes of terrestrial sediment flux, and climate changes of source areas both controlled the alternations of pollen assemblage in the Okinawa Trough. 
This work was supported by National Natural Science Foundation of China (Grant No. 41072128 and 40772113), the Fundamental Research Funds for the Central Universities (Grant No. 11 lgjc13 and 10lgzd08) and Young Scientist's Fund of the State Oceanic Administration of China. The samples were collected within the framework of the International Marine Past Global Changes Study (IMAGES) program during leg 4 with $R / V$ Marion Dufresne.

1. Sawada K, Handa N. Variability of the path of the Kuroshio ocean current over the past 25,000 years. Nature, 1998, 392, 592-595

2. Ujiié $\mathrm{H}$, Hatakeyama $\mathrm{Y}, \mathrm{Gu} \mathrm{X} X$, et al. Upward decrease of organic $\mathrm{C} / \mathrm{N}$ ratios in the Okinawa Trough cores: proxy for tracing the post-glacial retreat of the continental shore line. Palaeogeogr. Palaeoclimatol. Palaeoecol, 2001, 165, 129-140

3. Kawahata H, Ohshima H. Small latitudinal shift in the Kuroshio extension during the glacial times evidenced by pollen transportation. Quaternary Sci Rev, 2002, 21, 1705-1717

4. Li T, Xiang R, Sun R, et al. Benthic foraminifera and bottom water evolution in the middle-southern Okinawa Trough during the last 18 ka. Sci China, Ser B Earth Sci, 2005, 48, $805-814$

5. Zhou H, Li T, Jia G, et al. Sea surface temperature reconstruction for the middle Okinawa Trough during the last glacial-interglacial cycle using C37 unsaturated alkenones. Palaeogeogr Palaeocl, 2007, 246, 440-453

6. Kawahata H, Ohshima H. Vegetation and environmental record in the northern East China Sea during the late Pleistocene. Glob Planet Change, 2004, 41: 251-273

7. Chang Y P, Wang W L, Chen M T. The last 100000 years' palaeoenvironmental changes inferred from the diatom assemblages of core MD012404 from the Okinawa Trough, East China Sea. J Quaternary Sci, 2009, 24(8): 890-901

8. Yu H., Liu Z.X, Berné S, et al. Variations in temperature and salinity of the surface water above the middle Okinawa Trough during the past 37 kyr. Palaeogeogr Palaeocl, 2009, 281: $154-164$

9. Wang K, Sun Y H, The sporo-pollen and algal assemblages from the sediments of Okinawa Trough. Oceanologia et Limnologia Sinca, 1982, 13(5): 440-450

10. Wang, K F, Sun, Y H., Zhang, Y L, The sporo-pollen and algal assemblages in the sediment of the East China Sea. China Ocean Press: 1987, Beijing.

11. Song C Q, Sun X J, Yoshiki S. Paleoenvironmental information recorded by pollen in B-3GC gravity core in Okinawa Trough. Chinese Science Bulletin, 2001, 46 (11): 938-942

12. Chen J X, Zhang D Y, Zhang W Q, et al., The paleoclimatic change since the last glaciation in the north of Okinawa Trough based on the spore-pollen record. Acta Oceanologica Sinica, 2006, 28(1): 25—90

13. Deng Y, Zheng Z, Suc J-P, et al., Pollen Assemblages of the Last Glacial Maximum in Okinawa Trough and Their Implication on PaleoenvironmentEarth Science-Journal of China University of Geosciences, 2005, 30: 597—603 
14. Xu H Y, Chang F M, Luo Y L, et al. Palaeoenvironmental changes from pollen record in deep sea core PC-1 from northern Okinawa Trough, East China Sea during the past $24 \mathrm{ka}$. Chinese Sci Bull, 2009, 54: 3739-3748,

15. Xu D K, Lu H Y, Wu N Q, et al. 30000-Year vegetation and climate change around the East China Sea shelf inferred from a high-resolution pollen record. Quatern Int, 2010, 227 (1): 53-60

16. Bassinot F C, Michel E. Physical properties of sediment core MD98-2194. 2001, doi:10.1594/PANGAEA.59633

17. Stuiver M, Reimer P J. Extended $14 \mathrm{C}$ database and revised CALIB radiocarbon calibration program. Radiocarbon, 1993, 35: 215

18. Stuiver M, Reimer P J, Bard E, et al. INTCAL98 Radiocarbon Age Calibration, 24000-0 cal BP. Radiocarbon, 1998, 40(3): 1041-1083

19. Martinson D, Pisias N, Hays J D. Age dating and orbital theory of the ice ages: Development of a high resolution 0 300,000 years chronostratigraphy. Quaternary Res, 1987, 27, 1-29

20. Lisiecki L E, Raymo M E. A Pliocene-Pleistocene stack of 57 globally distributed benthic $\mathrm{d}^{18} \mathrm{O}$ records, Paleoceanography, 2005, 20, PA1003, doi:10.1029/2004PA001071

21. Sun X J, Luo Y L, Huang F, et al. Deep-sea pollen from the South China Sea: Pleistocene indicators of East Asian monsoon. Mar Geol, 2003, 201: 97-118

22. Zheng, Z, Yang S.X:, Deng Y., Huang K.Y., Wei J.H., Berne S. and Suc J-P., 2011 Pollen record of the past $60 \mathrm{ka} \mathrm{BP}$ in the Middle Okinawa Trough: terrestrial provenance and reconstruction of the paleoenvironment. Palaeogeography, Palaeoclimatology, Palaeoecology, 2011, 307: 285-300

23. Zheng Z, Huang K Y, Xu Q H, et al. Comparison of climatic threshold of geographical distribution between dominant plants and surface pollen in China. Sci China, Ser B Earth Sci, 2008, 51(8): 1107-1120

24. Ynag Q S, Xing Y W, Zhou Z K, Modern Geographical Distribution ofTsugaand Its Climatic Conditions in the Asian Monsoon Region. Acta Botanica Yunnanica, 2009, 31(5): 389-39

25. Deng Y, Zheng Z, Cour P, et al., Relation between pollen ratios and climate in East China and an attempt of paleoclimate reconstruction. Acta Plaeontologica Sinica, 2002, 41(4): 508516

26. Meng Xianwei, Du Dewen, Liu Yanguang, Han Yibing. Terrestrial flux in sediments from the Okinawa Trough and its response to climate changes over the past 35000 a. Acta Oceanologica Sinica. 2007, 29 (5): 74-80 (in Chinese with English abstract)

27. Jiang F Q, Li C A, Li T G, Geochemistry characteristics for core sediments of the southern Okinawa Trough and their paleoenvironment implication. Marine Geology and Quaternary Geology, 2002, 22(3): 11-17

28. Liu J P, Xu K H, Li A C, et al. Flux and fate of Yangtze River sediment delivered to the East 
China Sea. Geomophology, 2007, 85: 208—224

29. Xiong Yingqian and Liu Zhenxia. Variations in sediment provenance and its implications of Core DGKS9603 since the late Quaternary. Acta Oceanologica Sinica, 2004, 26 (2): 61-71 (in Chinese with English abstract)

30. Li G X, Liu Y, Yang Z G, et al., Primary study on the diapir in the north of the Yellow River delta. Science in China (Series D: Earth Sciences), 1999, 42 (2): 153-159

31. Yokoyama Y, Lambeck K, Deckker P D, et al. Timing of the Last Glacial Maximum from observed sea-level minima. Nature, 2000, 406, 713-716

32. Lea D W, Martin P A, Pak DK, et al. Reconstructing a 350 ky history of sea level using planktonic $\mathrm{Mg} / \mathrm{Ca}$ and oxygen isotopic records from a Cocos Ridge core. Quaternary Sci Rev, 2002, 21(1-3):283-293

33. Sun X, Luo Y. Pollen record of the last 280 ka from deep-sea sediments of the northern South China Sea. Sci. China (D), 2001, 44, 879-888

34. Li X, Sun X J, Palynological records since the last glacial maximum from a deep sea core in southern South China Sea. Quaternary Sciences, 1996, 6: 526-535

35. Heusser LE, Morley J J. Pollen and radiolarian records from deep-sea RC14-103: climatic reconstructions of northeast Japan and northwest Pacific for the last 90,000 years. Quaternary Res, 1985, 24, 60-72

36. Kawahata H, Ohshima H, Kuroyanagi A. Terrestrial - Ocean environmental change in the northwestern Pacific from the glacial times to Holocene. J Asian Earth Sci, 2011, 40:1189-1202

37. Igarashi K, Yamamoto M, Ikehara K. Climate and vegetation in Hokkaido, northern Japan, since the LGM: Pollen records from core GH02-1030 off Tokachi in the northwestern Pacific. J Asian Earth Sci, 2011, 40: 1102-1110

38. Wang Y J, Cheng H, Edwards R L, et al. A high-resolution absolute dated Late Pleistocene monsoon record from Hulu Cave, China. Science, 2001, 294: 2345—2348

39. Yuan D X, Cheng H, Edwards R L, et al. Timing, duration, and transitions of the last interglacial Asian monsoon. Science, 2004, 203: 575-578

40. Wang Y J, Cheng H, Edwards R L, et al. Millennial- and orbital-scale changes in the East Asian monsoon over the past 224000 years. Nature, 2008, 451: 1090-1093

41. Cheng H, Edwards R L, Wang X F, et al., Oxygen isotope records of stalagmites from Southern China. Quaternary Sciences, 2005,25(2):157-163

42. Heusser L. Northeast Asian climatic change over the last 140,000 years inferred from pollen in marine cores taken off the Pacific coast of Japan. In: M. Leinen and M. Sarnthein, Editors, Paleoclimatology and Paleometerology, Kluwer, Dordrecht (1989), pp. 665-692

43. Heusser L E, Morley J J. Monsoon fluctuations over the past 350 kyr: high-resolution evidence from northeast Asia/Northwest pacific climate proxies (marine pollen and radiolarians). Quaternary Sci Rev, 1997, 16, 565-581 
44. Petit J R, Jouzel J, Raynaud D. Climate and atmospheric history of the past 420,000 years from the Vostok ice core, Antarctic. Nature, 1999, 399, 429-436

45. Sun X J, Chen X D, Luo Y L, et al., An insight into paleovegetation on the emerged shelf at the Last Glaciation: pollen data of the South China Sea. Acta Botanica Sinica, 1999, 41(9): $1016-1023$

46. Ju L X, Wang H J, Jiang D B. Simulation of the Last Glacial Maximum climate over East Asia with a regional climate model nested in a general circulation model. Palaeogeography, Palaeoclimatology, Palaeoecology, 2007, 248: 376-390

47. Zheng Z, Cour P, Huang C X, et al.,, Dust pollen distribution on a continental scale and its relation to present-day vegetation along north-south transects in east China. Science in China Ser.D: Earth Sciences, 2007, 50(2): 236-246

\section{Tables:}

Table 1 AMS ${ }^{14} \mathrm{C}$ dates of the core MD982194 and age-control points based on the correlated $\delta^{18} \mathrm{O}$-dated events

\begin{tabular}{ccc}
\hline $\begin{array}{c}\text { Depth } \\
(\mathrm{cm})\end{array}$ & $\begin{array}{c}\text { Radiocarbon age/ } \\
\delta^{18} \text { O Tie-point }\end{array}$ & $\begin{array}{c}\text { Calibrated } \\
\text { calendar year } \\
\text { ( cal yr BP. })\end{array}$ \\
\hline 110 & AMS age: $11347 \pm 41$ & $12799 \pm 83$ \\
330 & AMS age: $22145 \pm 81$ & $26056 \pm 142$ \\
670 & MIS 3.31 & 55450 \\
900 & MIS 5.1 & 79250 \\
1230 & MIS 5.33 & 103290 \\
1370 & MIS 5.51 & 122560 \\
2920 & MIS 7.0 & 189600 \\
2930 & MIS 7.1 & 193030 \\
\hline
\end{tabular}




\section{Figures:}

Fig1. Map and isobathymetric topography of the East China Sea and the location of core MD982194 in the middle Okinawa Trough. In the top map, the arrows indicate the paths of ocean current: the Changjiang diluted water (CDW), the China Coastal Current (CCC), the Yellow Sea Coastal Current (YSCC), the Taiwan Warm Current (TWC), Yellow Sea Warm Current (YSWC), Kuroshio Current and the Tsushima Warm Current (TSWC). The bottom map shows the location of core MD982194 (star) and the continent shelf with upper than $-120 \mathrm{~m}$ depth contours was displayed with green color.

Fig.2. Correlation of $\delta^{18} \mathrm{O}$ of the present core MD 982194 (center) with oxygen isotopic stratigraphy of SPECMAP [19] and LR04 [20].

Fig 3. A plot of age-depth showing the sedimentation rate and the bulk density of the sediment for the core MD982194

Fig. 4 Pollen percentage diagram of core MD98219

Fig. 5 Comparison among Gymnosperm pollen taxa, brackish algae and oxygen isotope curve, showing the close relationship between high sea-level and increasing of pollen with bladders.

Fig. 6 Pollen diagram of selected herbs, fern spores and freshwater algae, showing that the increase of dryland and wetland herbs and freshwater algae was related with exposed flat plain when sea-level was lower at the glacial stages.

Fig.7 Shifts of coastline location respectively in the Glacial and interglacial stages, and changes of source areas of pollen supply and transport patterns, inferred by record of Okinawa Trough.

Fig. 8 Microscopic and scanned photos of pollen and charcoals which mainly derived from areas of short-distance transport during the glacial periods.

1-Asteraceae $(220 \mathrm{~cm}) ;$ 2-Typha $(480 \mathrm{~cm}) ; 3$-Chenopodiaceae $(2080 \mathrm{~cm})$; 4-Poaceae $(220 \mathrm{~cm}) ;$ 5-Cyperaceae $(530 \mathrm{~cm}) ;$ 6-Cryptomeria $(300 \mathrm{~cm}) ; 7-G l y p t o s t r o b u s ~(300$ $\mathrm{cm})$; 8-Phaeoceros $(380 \mathrm{~cm}) ; 9$-Ainsilaea type $(300 \mathrm{~cm}) ; 10$-Pediastrum $(460 \mathrm{~cm})$; 11-Cyperaceae (SEM $480 \mathrm{~cm}$ ); 12-Glyptostrobus (SEM, $310 \mathrm{~cm}$ ); 13-Poaceae (SEM, $310 \mathrm{~cm}$ ); 14-Glyptostrobus (surface granula in detail, $\mathrm{SEM} \times 25000,310 \mathrm{~cm}$ ); 15 -Charcoal and plant debris $(\times 400,300 \mathrm{~cm})$; 16- Charcoal and plant debris $(\times 100$, $480 \mathrm{~cm})$

Fig. 9 Percentage variation of herbs, pollen with bladders, terrestrial original algae 
and marine dinokysts in comparison with sea-level changes[32] and SPECMAP $\delta^{18} \mathrm{O}$, showing particularly the total herb related closely with sea-level fluctuation.

Fig.10 Correlation among typical pollen taxa, $\delta^{18} \mathrm{O}$ of stalagmite and solar insolation $\left(\mathrm{CO}_{2}\right.$ from Petit et al.,1999 ${ }^{[44]} ; \delta^{18} \mathrm{O}$ form Wang et al., 2008 $\left.{ }^{[40]}\right)$

Fig.11 Simulated annual-average precipitation (unit: $\mathrm{mm}$ /day) for the LGM minus the present by the RegCM2 and location of the core ( modified after Ju et al., 2007[46] ) 


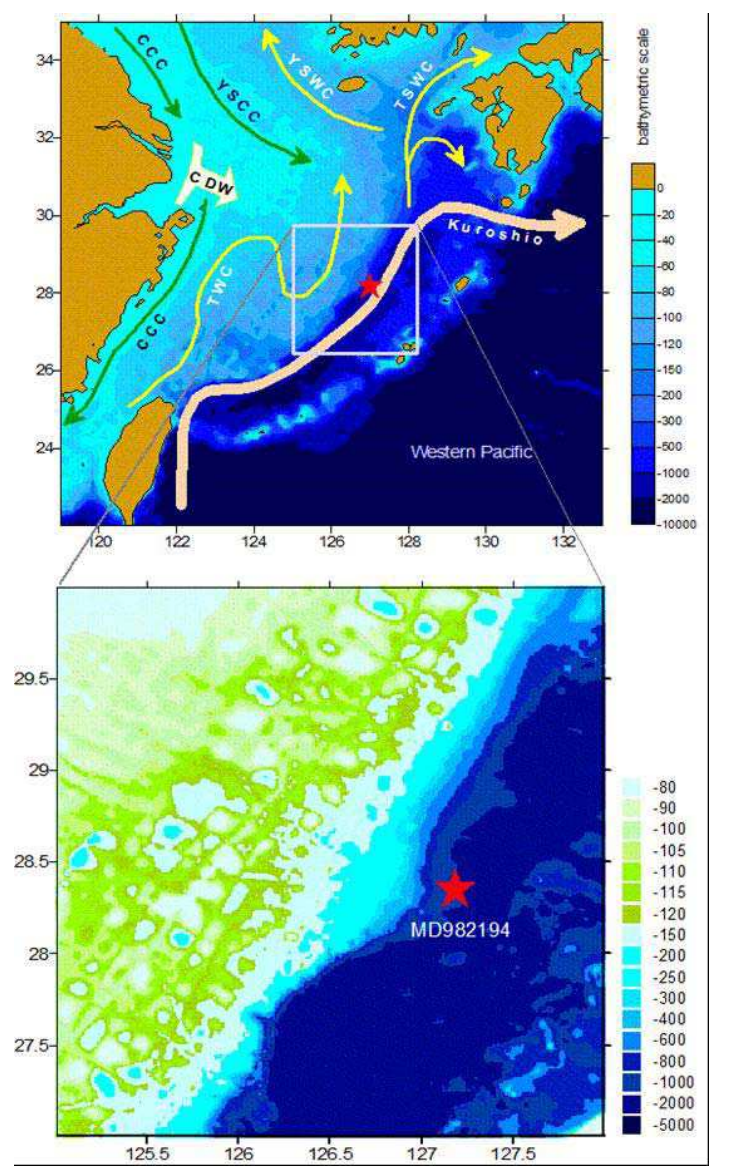

Fig1

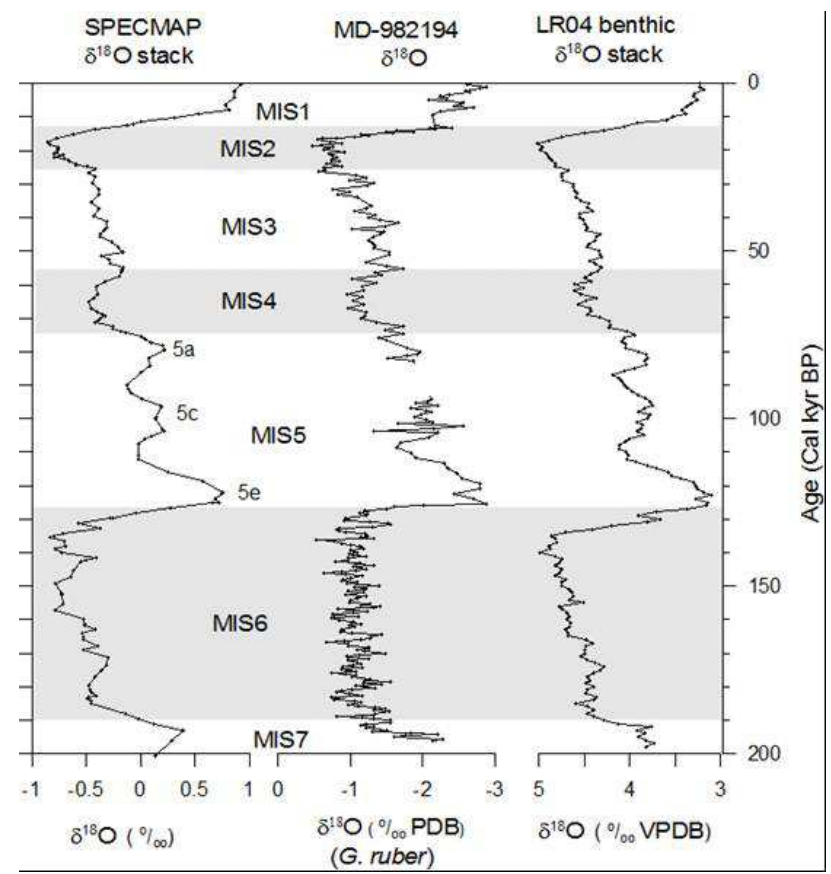

Fig 2 


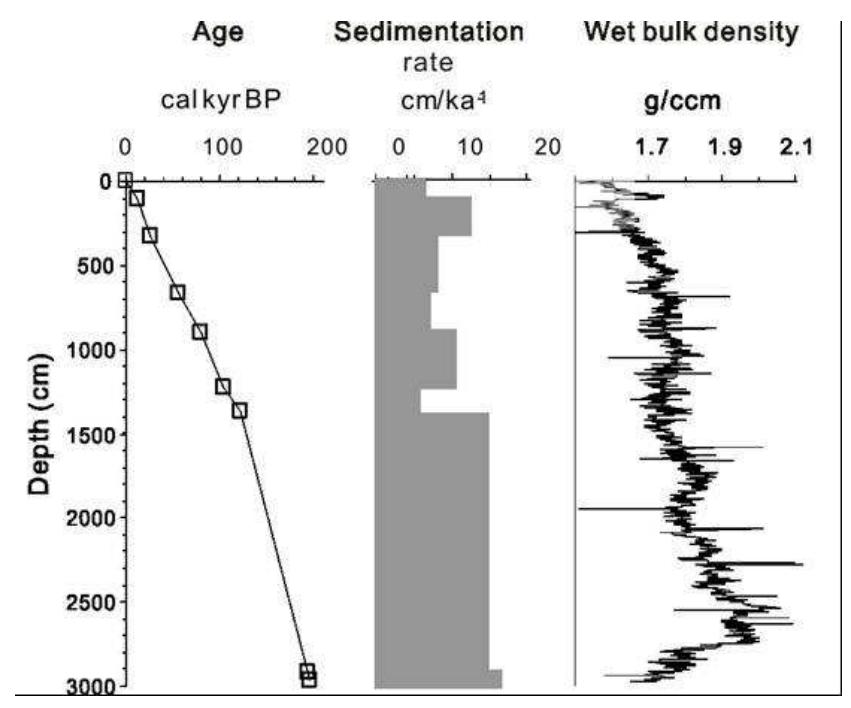

Fig 3 


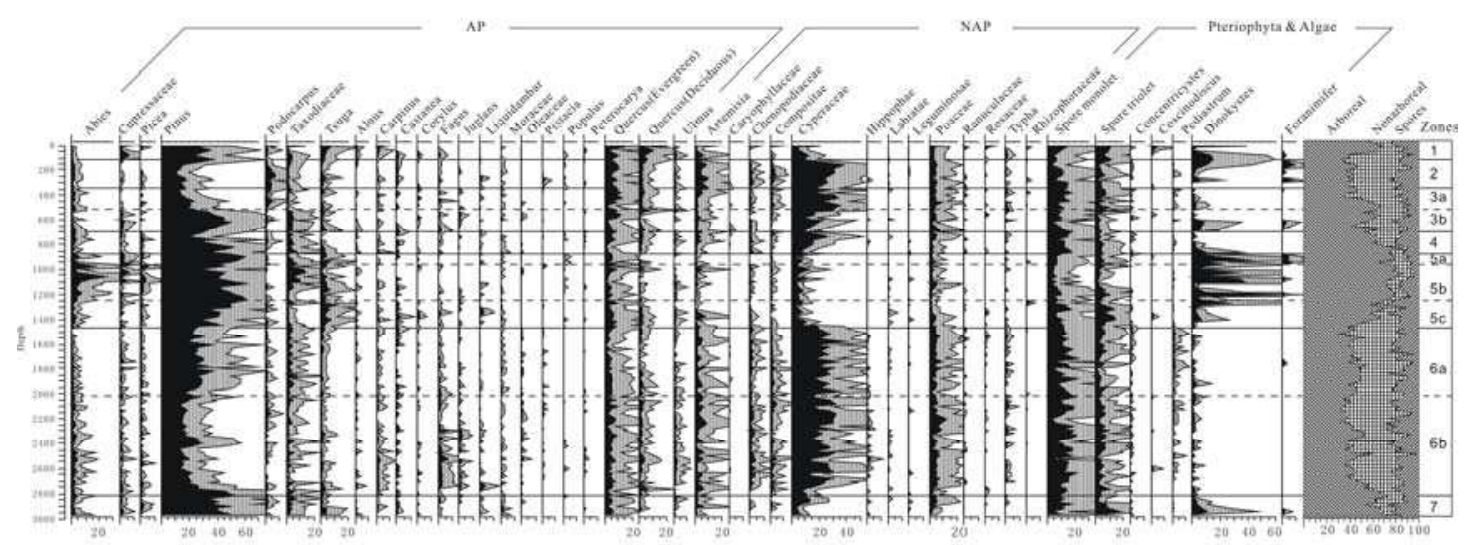

Fig 4

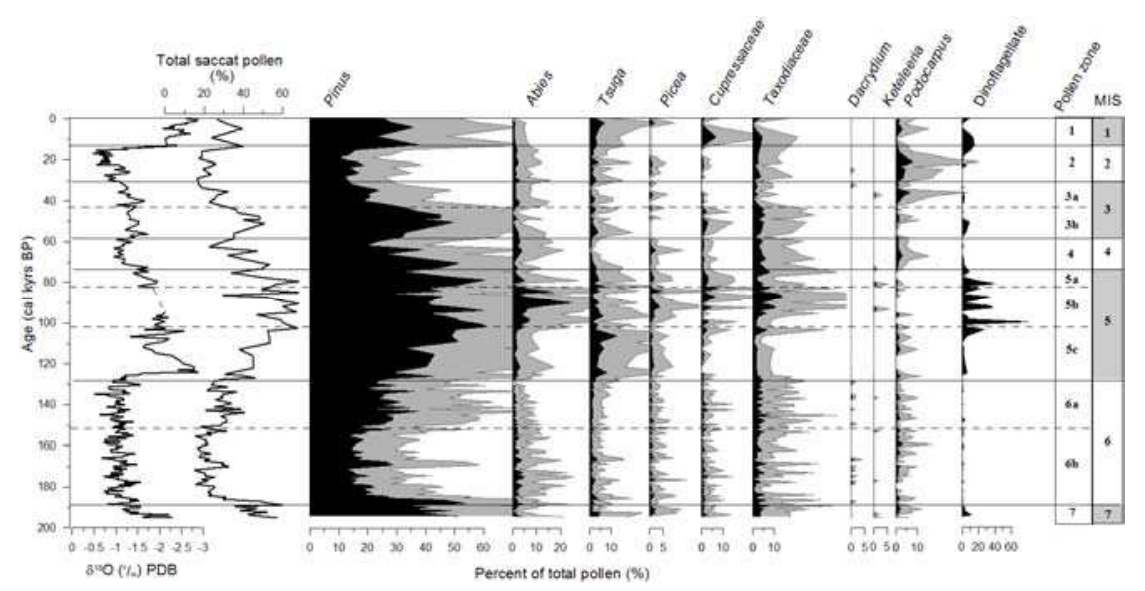

Fig 5

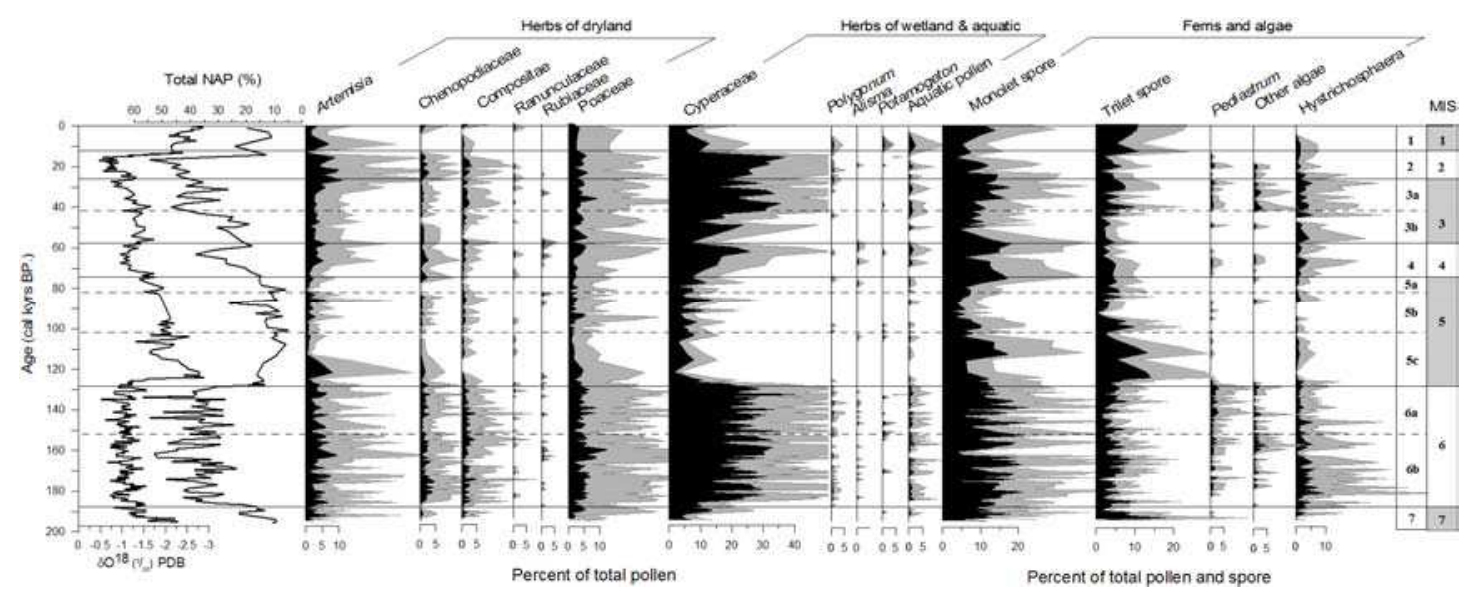

Fig 6 


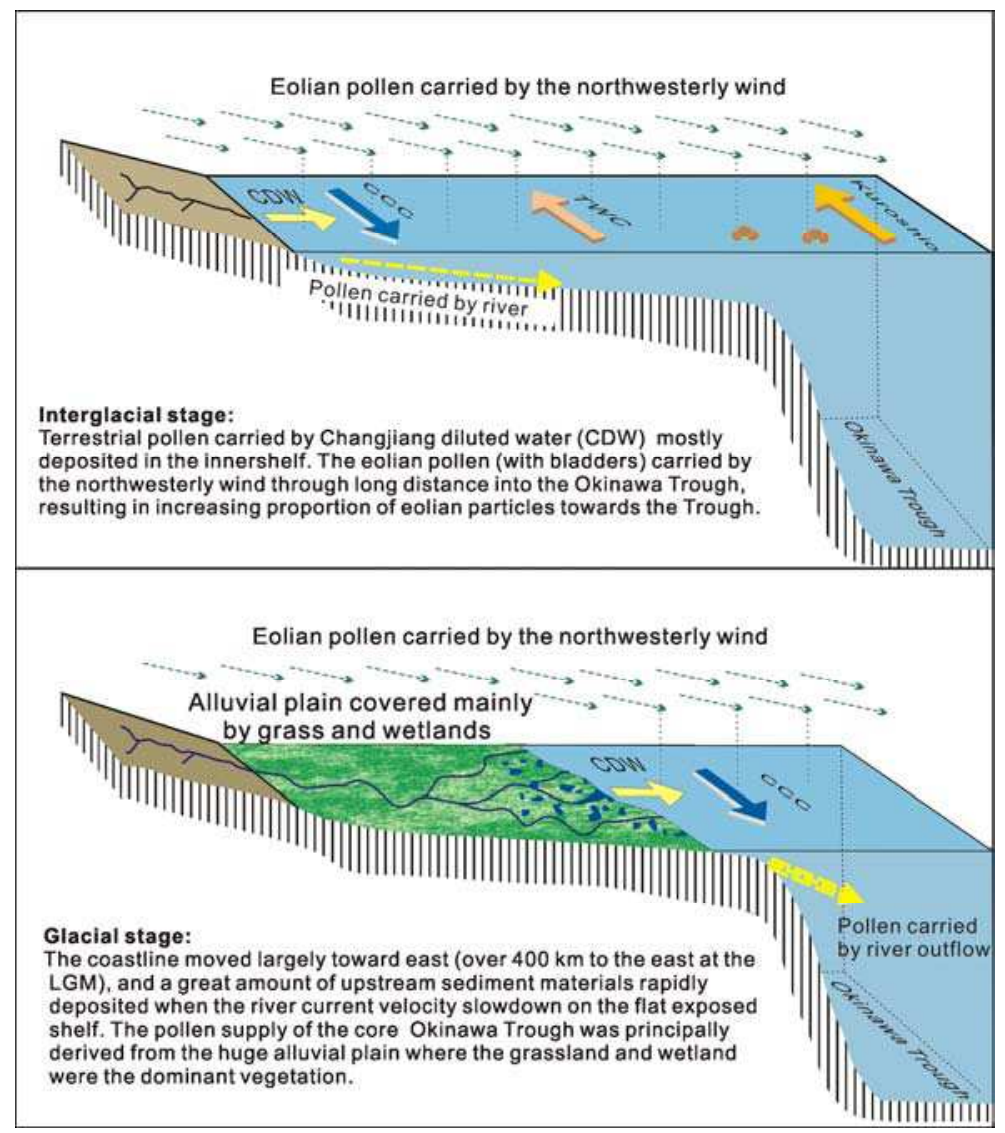

Fig 7

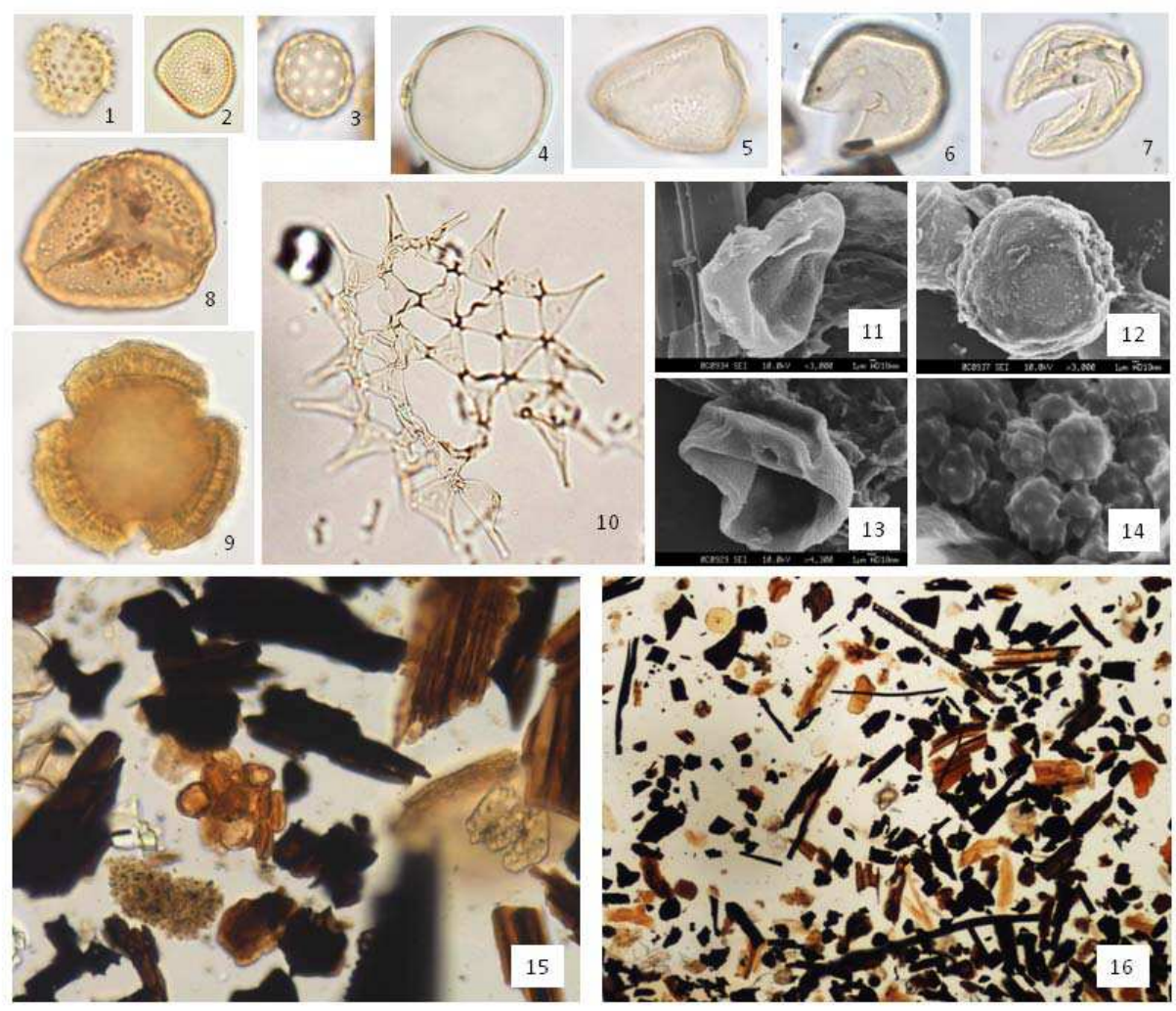


Fig 8

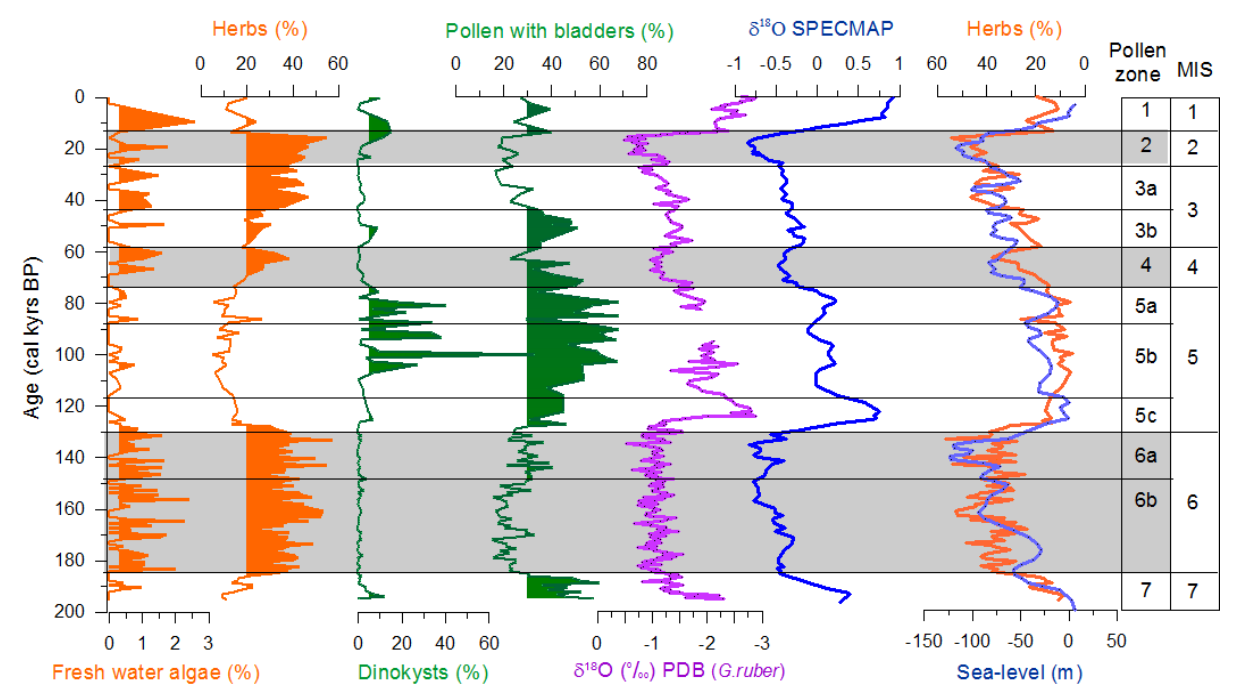

Fig 9

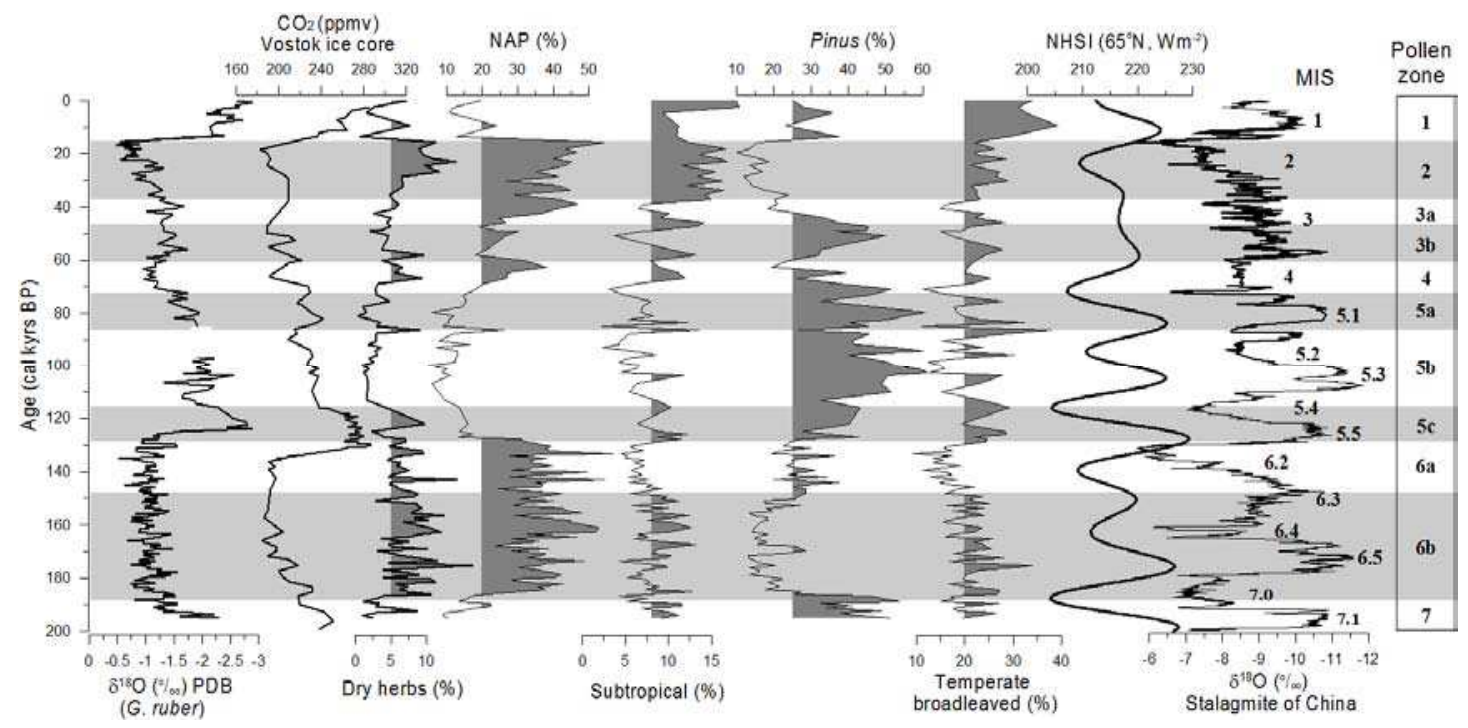

Fig 10 


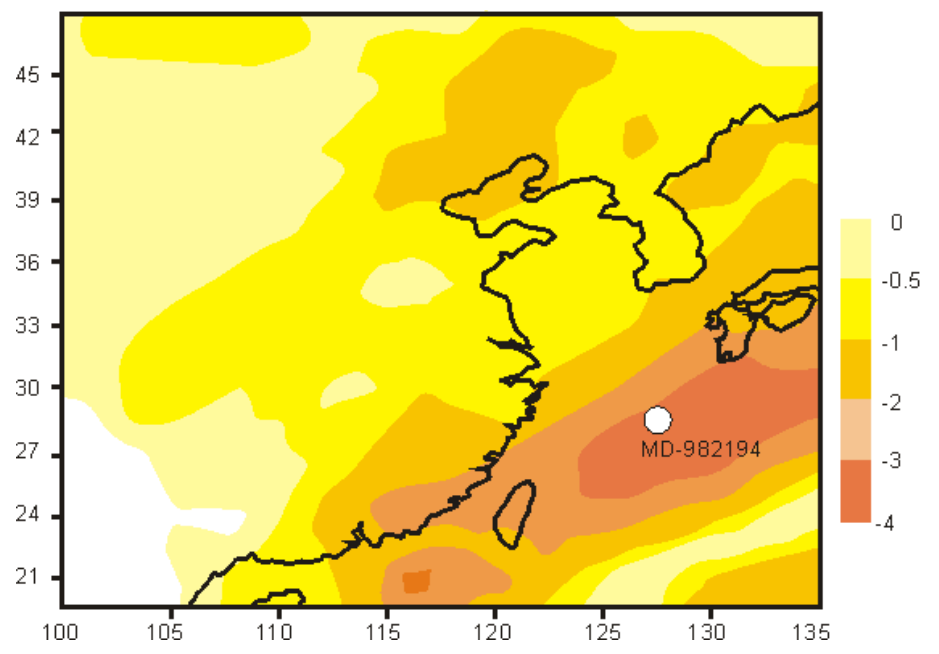

Fig 11 